\title{
Innovation in the food sector: Regional networks and internationalisation
}

\author{
X. Gellynck, B. Vermeire and J. Viaene \\ Ghent University, Faculty of Bio-engineering, Department of Agricultural Economics, Coupure Links 653, 9000 Gent, Belgium, \\ Xavier.gellynck@ugent.be
}

\begin{abstract}
This paper focuses on the role of regional networks in processes of innovation, in relation to internationalisation. The findings are drawn from a survey conducted in the food sector in the region of Meetjesland, Belgium. The initial aim was to find out which regional characteristics are strongly related to the innovation competence of the food sector, by applying discriminant analysis. The results pointed to two factors as being the most significant: firms are classified as having a stronger innovation competence when networking within the region, and when oriented towards the international market. This finding contains an apparent paradox, which is related to contemporary research pointing at the importance of the regional business environment for the firm's performance, but also at the benefit of internationalisation. In this paper it is argued that these theories are not contradictory, and that firms gain innovation competence by searching for external knowledge on different geographical scales. The results demonstrate that the innovators in the sample tend to be operating internationally and networking within the region. Both firms and policy makers can learn from this finding by acknowledging that the region is one of the geographical scales at which the firm can make a profit. Improving regional networks is therefore a way to gain innovation competence.
\end{abstract}

Keywords: region, internationalisation, innovation, networks

\section{Introduction}

Networks play an important role in innovation processes (Janszen, 2002; Pittaway et al., 2004; Daskalakis and Kauffeld-Mons, 2005). As the world economy is characterised by a trend towards further internationalisation, these networks increasingly take place on an international scale (Lu and Beamish, 2001; Myers, 1995). At present, firms are embedded in different national environments, as well as in the global business environment (Fletcher and Barett, 2001). Thus, networks can be located on these different geographical scales. Within this international perspective, the question rises how these international networks relate to regional networks of the firm.

This paper will shed light on the role of regional networks in innovation processes, complementary to the international business environment. The research question is tackled from a regional perspective, focussing on the extent to which regional networks contribute to innovation in food firms. Over the past decennia, innovation has become strongly directed by cooperation in networks. Success in innovation is seen as depending upon the flexibility of the enterprise, and the ability of the management to interact with outside firms and third actors. By joining a business network and taking part in a collaborative process with partners belonging to the network, the firm is able to overcome internal restrictions (Daskalakis and Kauffeld-Mons, 2005; Janszen, 2002; Camps, 2004).
In literature, different opinions exist on the role of the geographical scale of networks. Two different ways of thinking can be distinguished. First, many authors describe the positive impact of internationalisation on the firm's performance. Internationalisation is considered a natural evolution the firm passes through (Fletcher and Barrett, 2001; Lu and Beamish, 2001) or even a necessity (Bijman $e t$ al., 1998). By addressing new target markets and attracting foreign investments, firms are achieving a larger volume of production and growth. Further, as target markets are dissimilar to the original markets, new knowledge and capabilities need to be acquired (Lu and Beamish, 2001). Business networks are resources that can provide this knowledge and capabilities (Gulati, 1999). In the acquisition of knowledge by means of networks, a trajectory can be observed: a firm's networking activities start on the regional scale and move towards the international scale. This trajectory is not uniform: different internationalisation paths can be identified, depending on the sector and the specific regional context (Davenport, 2005).

The second way of thinking describes the positive contribution of the regional context to dynamics of innovation. Knowledge acquisition is assumed to benefit from geographic proximity (Davenport, 2003). The concentration of related economic activities in a region facilitates the flow of knowledge, resources and capabilities, which can lead to a competitive advantage for the firm. 
Firms operating in a global context also benefit from these regional relations.

This view is widely supported by regional development. The presence of contextual elements and interactions in the process of innovation is a key determinant of regional economic performance, which leads to an interest in regional development which is translated into different theoretical concepts, such as clusters (Porter, 1998) and National Innovation Systems (Iammarino, 2005; Lundvall, 1995). If the external environment is able to offer positive contributions in terms of innovative input, firms can incorporate this (de Noronha Vaz, 2004). This is also recognised by the European Commission, which listed regional policy (besides other policies) in the Green Paper on Innovation in 1995 (Kaufman and Wagner, 2005) as necessary to strengthen the competence for innovation. In this paper, the assumption is made that these two theoretical insights are not necessarily contradictory. Within a global internationalisation trend, research demonstrates the potential of the region to stimulate innovation. Further, the trajectory between regional and internationalised networks is not a fixed trajectory, and different strategies can be applied.

In this paper, the relation between regional networks and internationalisation is explored from the perspective of regional development. As the region wants to stimulate innovation, the influence of regional characteristics on innovation processes needs further research. In particular, the questions arise as to which regional characteristics have a strong relation to innovation processes, and how networks relate to them. Answering these questions enables us to formulate strategic measures to increase the innovation competence.

Building on these points, this paper draws conclusions about the role of regional networks in an international context, and demonstrates how regional networks contribute to innovation in an international business environment.

The paper is structured as follows. The next section presents the conceptual framework and formulates the research hypotheses, describing the relation between innovation, networks and regional development. The third section describes the research methodology: the area of research and the data collection. The fourth section sets out the main research findings and describes the role of the regional context in innovation processes. In the final chapter, conclusions are drawn with regard to networking and policy implications regarding innovation are studied.

\section{Conceptual framework and research hypotheses}

This section draws the theoretical outlines for the actual analysis. The three key concepts from the previous section - innovation, networks and the region - are situated within a conceptual framework. This enables us to formulate the research hypotheses. Figure 1 places the different building blocks in a conceptual framework.

In this paper, innovation is understood as an ongoing process of learning, searching and exploring, resulting in new products, new techniques, new forms of organisation and new markets (Lundvall, 1995). In this definition, two aspects are to be recognised.

First, a broad scope of domains is considered in the search for innovation. In most research, the focus is on innovation in large firms and high technology industries (Viaene and Avermaete, 2004). In this paper a new methodology is required, as the food sector can be considered as a lowtech industry, with a low intensity of R\&D. The analysis of innovation in terms of products, processes, organisational change and market choice answers to a sector where changes

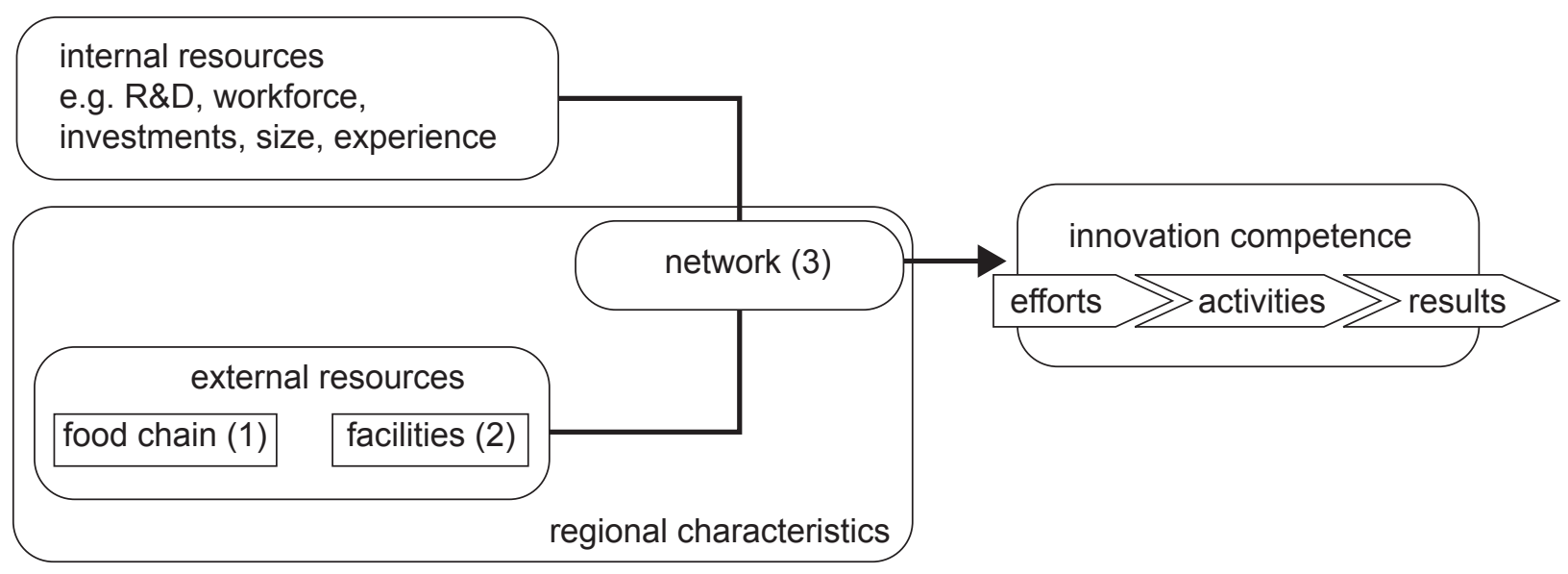

Figure 1. Conceptual framework. 
have taken place which are not technological, yet drastic (Earle, 1997).

Second, different moments in the process of innovation are viewed: the efforts and activities as well as the results of the process are studied. The focus on the process of innovation is related to a management-oriented approach centred upon how innovations are developed, on the mesoand firm-level (Omta, 2004b). Not only are the successful innovations considered, but also the process of trial and error that characterises the development of innovations. Thus, innovation competence does not indicate the mere outcome of an innovation - a successful introduction - but also addresses the capacity to innovate in the future.

The process of innovation is driven by both internal and external resources (Cassiman and Veugelers, 2002; Janszen et al., 2002). Internal resources refer to the $R \& D$ structure, and a vast number of firm characteristics such as size, financial structure, qualified staff, experience of the manager and openness to new ideas all have an influence on innovative processes (Grünert et al., 1997; Diederen et al., 2000; Romijn and Albaladejo, 2002; Fey and Birkinshaw, 2005).

This paper focuses on the role of external resources in innovation processes. This does not imply that the impact of external resources on other geographical scales (e.g. national) and internal resources are not acknowledged. On the contrary, our analysis supports the presence of additional variables explaining innovation competence. External resources encompass the contextual elements contributing to innovative processes with regard to the inflow of knowledge from other places (Iammarino, 2005). As depicted in the conceptual framework, this research focuses on external resources on the regional scale.

The firm extracts information from other commercial and societal actors, such as firms, research institutes, universities and governments (Omta, 2004b). In this research three characteristics of the region are considered: the food chain, facilities and networks. They are understood as aspects of the regional production environment, having a potential impact on the innovation competence of firms. There is a connection between the firm and the environment, which serves as a potential flow of knowledge to the firm (Avermaete, 2003). The firm may or may not make use of this connection.

The conceptual framework (Figure 1) shows two types of external resources being considered as regional characteristics. First, there is the regional food chain, i.e. the set of competitors and suppliers in related sectors. Second, there is a broad spectrum of regional facilities, such as: knowledge, institutions, infrastructure, government support, qualified labour and the market.

The binding component in the conceptual framework is the network. As described in the introduction, taking part in networks is a way to overcome internal restrictions in the process of innovation (Daskalakis and Kauffeld-Mons, 2005). At present, the acquisition of external knowledge and the use of internal resources are considered complementary in innovation processes (Cassiman and Veugelers, 2002). The conceptual framework describes networks as the means of exchange between the firm's internal and external resources in the process of developing innovation competences. It is argued that the actual interaction between actors should be distinguished from the presence of the food chain and facilities (Oerlemans et al., 2001) As such, the network is understood as the lubricant for the combined transformation of internal and external resources into an innovation.

Networks are considered to be embedded in the environment (Etkowitz and Klofsten, 2005), which can cover different geographical scales (Bunell and McCoe, 2001). For formalised networks (e.g. employers' associations, innovation networks) this position is clear. But informal networks also depend upon the presence of actors and knowledge. As this paper focuses on regional networks, the presence of networks on this specific geographical scale is recognised as a regional characteristic in the conceptual framework (Figure 1). It is the condition for exchange between the firm and the regional food chain and facilities.

As noted above, literature acknowledges the relation between regional networking and innovative processes. Further, literature describes how the firm benefits from internationalisation. Therefore, the question arises as to whether regional networking indeed makes a significant contribution to the firm's innovation competence and, if so, if this also holds true for the internationalising firm.

Consequently, two research hypotheses are formulated. First, firms participating actively in regional networks are more innovative than the ones that are not participating. Second, regional networks contribute to innovation within an international business environment. To verify this, a set of regional factors is constructed and their potential to explain the firm's innovation competence is analysed. The analysis demonstrates that the intensity of regional network relations has the power to predict innovation competence and the relation to the market orientation of the firm.

\section{Research methodology}

The analysis of innovation competence in relation to regional characteristics is based on primary data collected through a questionnaire among food firms in Meetjesland, a region in the province of East-Flanders, Belgium (Figure 2). Meetjesland can be characterised as a rather small region, comprising 93,883 inhabitants and a territory of $500 \mathrm{~km}^{2}$ (Streekplatform Meetjesland, 2005). Within the European 


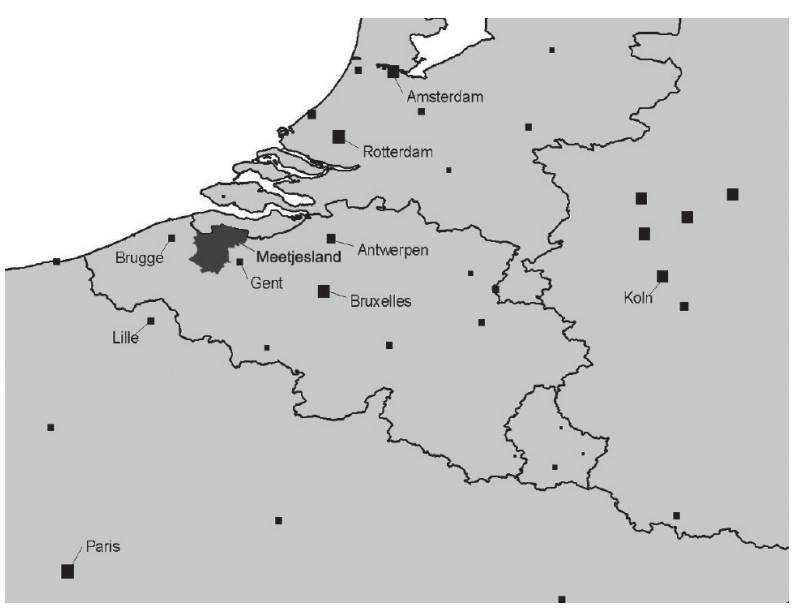

Figure 2. Meetjesland situated in Western Europe.

context it is selected as a Leader+ area, being less prosperous with an average income below the Flemish average. It is a low-density area with 228 inhabitants $/ \mathrm{km}^{2}$, which is lower than the Flemish average of 444 inhabitants $/ \mathrm{km}^{2}$ (in 2003).

The region is a rural area in the proximity of a number of strong economic complexes: the city and harbour of Ghent in the East and the regions of Bruges and Kortrijk in the West. The region is characterised by a specialisation in agri-food. It houses an important agricultural sector, specialised in meat production (pig and cattle) and horticulture (Gellynck et al., 2004). In line with this agricultural specialisation, food manufacturing has developed into an important sector. It is specialised in meat processing, representing $27 \%$ of the total population of food firms and $46 \%$ of the added value realised in the regional food sector (Vermeire et al., 2005). A vast majority (95\%) of the businesses in Meetjesland are SMEs with less than 100 employees, and there are only a few large, internationally orientated firms (5\%).

The sample consists of 81 firms, which is $50 \%$ of the total number (163 firms). Most of the sectors and chains in the agri-business industry are sufficiently represented in the sample. The sector chocolate and sugar confectionary is slightly under-represented. The respondent in most cases was the general manager, or the manager of Quality Assurance/R\&D.

Data were gathered among three levels of the agri-business complex: food processing firms, trade firms (wholesale trade) and their main suppliers (excluding farmers). The survey was conducted in March and April 2005. The questionnaire had three main goals:

- to determine the innovation competence of the firm;

- to measure the strength of the relation between the firm and the regional characteristics (regional networks, agrifood chain and facilities);
- to evaluate current and future actions stimulating innovation and networking.

The research was conducted as follows. First, firms were classified in terms of their innovation competence by means of cluster analysis. Second, factor analysis permitted us to recognise basic dimensions in the relation between the firm and the regional characteristics. Third, we calculated which of these regional factors have the strongest ability to predict the classification in terms of innovation competence, applying discriminant analysis. In the next section the three steps are further explained, and the main findings are described.

\section{Research findings and discussion}

\section{Three clusters of innovation competence}

By means of cluster analysis the firms were classified as being a non-innovator, a follower or an innovator. These three clusters have an optimal internal resemblance, based on a set of variables that indicate the firm's innovation competence (Malhotra, 1999; De Pelsmacker and Van Kenhove, 1994). This classification permits us to relate statements on regional characteristics to the innovation competence of the firm in further analysis.

The selection of variables is grounded in the definition of innovation by Lundvall (1995) as described in the introduction. In this definition three significant aspects of innovation are recognised: efforts, activities and results. Further, Lundvall sees innovative processes as taking place in four domains: product- and process innovation, organisational innovation and innovation in market choice.

The application of this definition, focusing on a broad range of activities, is different from innovation studies that mainly address specific aspects of innovation, and generally aim at technological innovation (Clarysse et al., 1998; Lundvall, 1995; Avermaete et al., 2003).

Following this concept of innovation, four variables were selected to measure the firm's innovation competence. The first and second variables measure the efforts in innovation: one refers to the intensity of $R \& D$, and one refers to implicit methods of knowledge acquisition. The acquisition of knowledge is considered the main driving force in innovation processes (Etkowitz and Klofsten, 2005; Cassiman and Veugelers, 2002), and R\&D statistics are widely applied as an indicator of the firms' innovation competence (Romijn and Albaladejo, 2002). Yet, research demonstrates that, especially among SMEs, only a minority of the firms structurally invest in R\&D (Avermaete, 2004). As a consequence, the analysis includes a variable referring to the efforts of the firm in what is characterised as 'implicit' 
methods of knowledge acquisition: education and training, study, seminars, field work and others.

The third variable measures the innovative activities. Activities involve the development of innovations, following from a number of efforts, and in the end leading to a number of results. To measure this, a variable describing the overall innovation activity is obtained. Innovation is considered a multi-facetted process, and the outcome of a set of competencies that are built over time and relate to the orientation of the firm (Harmsen et al., 2000). Therefore, innovation activities are intensive if they are performed in the four domains of innovation mentioned above.

To measure results, the respondent was asked to indicate the importance of the applied innovative activities for the firm. This indicator refers to a general evaluation of the firm, comprising both tangible (e.g. growth of market share, profit) and less tangible aspects (e.g. firm stability, efficiency) due to innovation.The results of the cluster analysis are summarised in Table 1. A three-cluster solution was obtained. The number of clusters was determined by the agglomeration coefficients in hierarchical cluster analysis. In a following step, the K-means cluster method was performed to classify the respondents and to calculate the final cluster centres. Clusters are labelled as non-innovators, followers and innovators.

Three out of four variables are significantly different between the clusters: the R\&D budget, the number of domains of innovation and the importance of the innovation. There is a difference between the two variables indicating the intensity of knowledge acquisition. A significantly higher percentage of firms in the innovators cluster invest in R\&D than in the other innovative classes. Notably different are the cluster centres of man-hours in implicit knowledge-acquisition, where no significant differences between the group means are found.

\section{Identifying the regional factors}

In the second step of the analysis, aspects of the regional environment were analysed using factor analysis. This technique was applied to recognise the underlying regional factors among the larger set of interrelated variables (Malhotra, 1999; De Pelsmacker and Van Kenhove, 1994). Factor analysis permitted us to acquire a clear view of the variables, and to recognise relationships between the treated aspects.

A set of variables was gathered to measure the strength of the relation between the firm and the region. The selection of variables resulted from exploratory research by means of secondary resources and in-depth interviews, in cooperation with a regional development organisation (Regional Platform Meetjesland). As such, the variables refer to regional characteristics for innovation being applied to the specific regional context. Further, the factors could be used to fine tune the conceptual framework. In a later step of the analysis, the factors served as independent variables for discriminant analysis.

A number of eight extracted factors was fixed by the Scree Plot, and resulted in a satisfactory level of variance explained (67\%). Table 2 shows the eight factors that were calculated. Loadings less than .5 were omitted in order to get a clear picture. The factors were labelled by interpreting the variable loadings per factor.

The table demonstrates that factor 5, the regional networking factor, describes the role of networks. In particular, a correlation is shown between variables referring

Table 1. Description of final clusters.

\begin{tabular}{lllll}
\hline Variable & \multicolumn{2}{l}{ Clusters } & & \\
\cline { 2 - 5 } & Non-innovators & Followers & Innovators & Sig. \\
& & & & - \\
Number of respondents & 31 & 33 & 12 & $.007^{*}$ \\
Mean differences in one way ANOVA & & & $-0.3^{\mathrm{b}}$ & .073 \\
Budget in R\&D & $-0.3^{\mathrm{a}}$ & $-0.2^{\mathrm{a}}$ & 0.0 & $.000^{*}$ \\
Man-hours in implicit knowledge acquisition & -0.3 & $0.5^{\mathrm{b}}$ & $1.2^{\mathrm{c}}$ & $.000^{*}$ \\
Number of domains of innovation & $-1.0^{\mathrm{a}}$ & $0.5^{\mathrm{b}}$ & $1.8^{\mathrm{c}}$ & \\
Importance of the innovation & $-1.0^{\mathrm{a}}$ & & & \\
\hline
\end{tabular}

* Sig. $<0.05$ (One-way ANOVA)

Procedure: Hierarchical Cluster Analysis (Ward's method) \& subsequent K-means method

Distance Measure: Euclidean Squared Distance

Superscript indicates significant differences between group means in Duncan's Test 
to networking with a variety of actors via a variety of media. It mainly concerns networking with regional competitors, participation in societal activities and in economic networks and contact with knowledge centres. The actors involved in the networks are also reflected in the two other regional characteristics: regional facilities and the regional food chain. Regional networks are the medium by which the agri-business firm exchanges information and resources within the region. As such, regional networks are recognised as a separate factor, as is the case in the conceptual framework.

The regional networking factor is not only related to business-to-business networks (regional competitors), but also the networks of food firms with a range of public and private actors, such as government, research centres, employers' associations or social organisations.
Thus, networks are perceived as the central medium for interaction. Further, this interaction via networks can take place at different intensities, and can be both formal and informal.

Factors 1, 3 and 6 relate to the importance the respondent attaches to public support and policy. However, the factors involve different aspects of public support. The first factor is strongly related to the importance attached to the socio-economic environment. The third factor deals with important qualities of setting, which contribute to a good investment climate. The sixth factor contains a number of public services that support economic activity, but also improve qualities of setting (infrastructure, taxes).

\section{Predicting innovation competence}

Table 2. Factor loadings.

\begin{tabular}{|c|c|c|c|c|c|c|c|}
\hline \multicolumn{2}{|l|}{1 Socio-economic factor } & \multicolumn{2}{|c|}{$\begin{array}{l}2 \text { Relation to competitors \& suppliers } \\
\text { factor }\end{array}$} & \multicolumn{2}{|c|}{3 Qualities of setting factor } & \multicolumn{2}{|c|}{$\begin{array}{l}4 \text { Regional market orientation } \\
\text { factor }\end{array}$} \\
\hline Variable & $\begin{array}{l}\text { Factor } \\
\text { load }\end{array}$ & Variable & $\begin{array}{l}\text { Factor } \\
\text { load }\end{array}$ & Variable & $\begin{array}{l}\text { Factor } \\
\text { load }\end{array}$ & Variable & $\begin{array}{l}\text { Factor } \\
\text { load }\end{array}$ \\
\hline Image of close environment & .811 & Competition with competitors & .849 & Proximity of suppliers & .707 & $\begin{array}{l}\% \text { customers within } \\
\text { region }\end{array}$ & .885 \\
\hline Image of region & .781 & $\begin{array}{l}\text { Exchange of information with } \\
\text { suppliers }\end{array}$ & .822 & Subsidies & .704 & $\begin{array}{l}\% \text { competitors within } \\
\text { region }\end{array}$ & .842 \\
\hline Promotion of regional business & .771 & Observation of competitors & .742 & Transport facilities & .688 & Proximity of customers & .535 \\
\hline Promotion of the region & .629 & Imitation of competitors & .688 & Support to networking & .593 & & \\
\hline Social policy & .527 & & & & & & \\
\hline Information provision & .523 & & & & & & \\
\hline 5 Regional networking factor & & 6 Public support factor & & 7 Secrecy factor & & 8 Indifference factor & \\
\hline Variable & $\begin{array}{l}\text { Factor } \\
\text { load }\end{array}$ & Variable & $\begin{array}{l}\text { Factor } \\
\text { load }\end{array}$ & Variable & $\begin{array}{l}\text { Factor } \\
\text { load }\end{array}$ & Variable & $\begin{array}{l}\text { Factor } \\
\text { load }\end{array}$ \\
\hline Participation in societal activites & .896 & Care for infrastructure & .746 & $\begin{array}{l}\text { Secrecy of processes } \\
\text { towards competitors }\end{array}$ & .812 & $\begin{array}{l}\text { Indifference towards } \\
\text { regional competitors }\end{array}$ & -.819 \\
\hline Participation in networks & .824 & Economic consultancy & .590 & $\begin{array}{l}\text { Secrecy of processes } \\
\text { towards suppliers }\end{array}$ & .767 & $\begin{array}{l}\text { Indifference towards } \\
\text { regional suppliers }\end{array}$ & -.694 \\
\hline $\begin{array}{l}\text { Exchange of information with } \\
\text { competitors }\end{array}$ & .534 & Tax level & .590 & & & $\begin{array}{l}\text { Proximity of knowledge } \\
\text { centres }\end{array}$ & .623 \\
\hline Contact with knowledge centres & .508 & $\begin{array}{l}\text { Information and reception of } \\
\text { newcomers }\end{array}$ & .549 & & & & \\
\hline
\end{tabular}

Extraction method : Principal Component Analysis (PCA)

Rotation method : Varimax

Factor loadings less than .500 are omitted 
In the next step of the analysis the aim was to measure the strength of the relation between the regional factors and the classification in terms of innovation. Discriminant analysis enabled us to determine which factors have the strongest relation to innovation competence by calculating a function that predicts classification as a non-innovator, follower or innovator (dependent variable), using the factors as independent variables.

The direct method was used, in order to estimate the discrimination based on all the predictors (factors). The discriminant function is shown in Table 3. The function was able to predict the group membership of $73 \%$ of the cases. This is $40 \%$ higher than an allocation by coincidence (one out of three). Thus, the function has a strong explanatory power.

Nevertheless, this function cannot be expected to give the entire explanation for the innovation competence of the firm. As internal characteristics of innovation competence are not included in the analysis, the function only gives information about the external factors of innovation. In the discriminant function, two factors are of particular importance: regional networking and regional market orientation. Less significant, but also important, is the relation to competitors and suppliers. The other factors have a smaller weight in this function.

The regional networking factor has the strongest positive relation with the classification in terms of innovation competence. This implies that firms which interact via networks and societal activities, and that exchange information with competitors and have contact with knowledge centres. are likely to be classified as having greater innovation competence.

Strong orientation of agri-business firms toward the regional market (having a large percentage of suppliers and customers within the region) results in a lower innovation competence.
On the other hand, the firms in the sample that locate their competitors and customers on the international scale are more innovative.

Thus, the discriminant function reveals a substantial difference in the relation of innovation competence with regional networking on the one hand, and with regional market orientation on the other hand.

This implies that innovators tend to operate on the international scale and to invest in regional networking. Non-innovators, in turn, engage less in regional networking, but are likely to have the regional environment as their main area of activity. This finding demonstrates that investing in regional networking and internationalising the market orientation are both good ways to increase innovation competence.

A smaller discriminant loading is addressed to the relation with competitors and suppliers factor. This factor is negatively correlated with innovation competence and with the regional networking factor. This finding is remarkable as the regional networking factor includes the exchange of information with competitors (Table 2). Thus, while exchange with competitors, as part of factor 5 , is positively related to innovation competence, imitation and competition, as part of factor 2, are not.

A partial explanation is found by looking closer at the variables that load on the factor. Table 4 shows that innovators are significantly more indifferent towards competitors in the region, and are less inclined to imitate or compete with regional competitors. The variable exchange of information with suppliers, which also loads on the factor, is not included in the table as the significance of mean differences is very low for this variable: all three clusters have an intensive exchange of information with suppliers.

The table suggests that the significantly low scores of innovators are linked to their limited regional market

Table 3. Discriminant function predicting cluster membership.

Innovation competence $=$

$.697 *$ Regional networking

$+-.340 *$ Regional market orientation

$+-.249 *$ Relation to regional competitors and suppliers

$+.154 *$ Indifference

$+.101 *$ Qualities of setting

$+.100 *$ Secrecy

$+-.079 *$ Public support

$+.060 *$ Socio-economic factor

Wilks' Lambda: .024

Canonic correlation: .672 
Table 4. Analysis of variance (one way ANOVA) on regional competitor relations.

\begin{tabular}{lllll}
\hline $\begin{array}{l}\text { Characteristics of regional } \\
\text { competitor relations }\end{array}$ & Non-innovators & Followers & Innovators & Sig. \\
Imitation & $2.00^{\mathrm{b}}$ & $1.63^{\mathrm{ab}}$ & $1.25^{\mathrm{a}}$ & $.028^{*}$ \\
Competition & $3.15^{\mathrm{b}}$ & $2.69^{\mathrm{ab}}$ & $2.26^{\mathrm{a}}$ & .071 \\
Indifference & $1.76^{\mathrm{a}}$ & $1.75^{\mathrm{a}}$ & $2.85^{\mathrm{b}}$ & $.008^{*}$ \\
\hline
\end{tabular}

* Sig. $<.050$

Superscript indicates significant differences between group means in Duncan's test

orientation: regional competitor relations are less intense as competitors are found on a wider geographical scale. Even though factor analysis calculates factors which are by definition not correlated, it is noticeable that an international market orientation causes an increase of indifference in terms of regional imitation, competition and observation. Nevertheless, a remarkable observation is that this is not the case for the exchange of information with competitors, which loads on the regional networking factor. Exchange of information with competitors consequently serves a different goal.

The positive relationship between regional networking and innovation competence is clearly demonstrated. On the other hand, analysis does not supply arguments to decide on the direction of this relationship. Knowledge of this direction is necessary to really come to grips with the dynamic of regional networking. Different hypotheses are possible: it can be hypothesised that the positive relation is caused by the ability of regional networks to translate regional knowledge and qualities into a significant innovation input. But the contrary is also possible: the success of networking could be due to particular firms or sectors. Depending on this direction, regional networks can be characterised as a medium generating innovation, on the one hand, or as a regional forum where innovating firms meet, on the other hand (or an in-between position could be assumed).

The discriminant function contains an apparent paradox: regional networking contributes to innovation competence, while a regional market orientation attains the opposite. This seems paradoxical on behalf of the non-innovator: he does not interact with the region even though the region is his main area of activity. But it may also seem paradoxical on behalf of the innovator: his competitors and customers are located on the international market, but nevertheless, the innovator invests in regional networking.

The explanation of this paradox follows the introduction of this paper, which described the different possible strategies of internationalisation. Further, the statement is defended that as firms operate within a global business environment, network relations develop on and in between different geographical scales. One of these scales is the regional scale, and findings suggest that integrating the regional scale within an internationally oriented business model can result in benefits in terms of innovation competence.

In the sample, the firms that are active on the different scales are classified as having a stronger innovation competence. In the described behaviour, networking within the region complements an international market orientation. Thus, the different geographical scales of networks and business environments interact.

Firms that succeed in estimating the possible benefits on each of the different scales, and strategically invest in them, yield the fruits of different regional and international business relations. This is in line with the statement of Bunnell and Coe (2001) that attention should shift away from innovation in bounded spaces, towards greater attention for the connections that support such spaces. In this vision, looking at a geographical scale as a 'container' neglects the impact of broader networks that support innovation in particular locales.

Regional authorities that support networking and innovation can learn from these theoretical statements by acknowledging the importance of interconnectedness rather than the territorial aspects of networks. The region can increase its innovation competence by offering the factors that help firms successfully benefit from networking relations: thus increasing the benefit of a firm's external resources that are present in the region, and supplying the means to reach external resources that are found outside the region. The region may offer regional networks to connect to both local and international partners.

\section{Conclusions}

This research showed that factors related to the attitude and strategy of regional networking have the strongest potential to discriminate between clusters of firms representing 
various levels of innovation competence. Firms that participate in regional networks are thus more innovative than those that do not. Regional networking appears to be more important than the particular use of regional facilities or the presence of a strong regional food chain. This suggests that the firms' attitude toward networking is decisive: it is the condition that has to be fulfilled to fully benefit from regional external resources for innovation.

Second, the research demonstrated that participation in regional networks and international market orientation are complementary in improving innovation competence. In the discriminant function, combining regional networking with an international market orientation results in increased innovation competence. This implies that innovators are predominantly oriented toward the international market, but interact intensively within the region. Within an international business reality the regional network makes sense. This confirms theoretical insights stating that business and innovation happen on and in between different geographical scales.

This has strategic implications for policy makers. Regional networks are an instrument to improve the economic performance of the region. Moreover, these networks have the potential to upgrade firms that have less innovation competence. Analysis shows that these firms generally have a national or regional market orientation. As such, the regional scale is well suited to address these firms.

The aim is to optimise the flow of knowledge and resources within the region and at the same time stimulate firms to open up towards the international business reality.

From the firm's perspective, this paper leads to the conclusion that innovative firms consider regional characteristics when determining their business strategy. In a global market where growth is pursued by internationalisation, the firm is actively searching for the resources to realise this. Therefore, an active search on different geographical scales is promising. In this search, the regional level proves to be one that can significantly contribute to innovation. However, it can be expected that the possible benefits of regional networks depend upon the characteristics of the firm and the specific region.

This analysis leads to a number of topics for further research. First, further questions arise related to the evolution in networking strategies between different geographical scales. Do internationally oriented firms evolve from a regional network environment towards an international network environment, or is there an opposite trajectory, in which internationally oriented firms start to invest in regional networks?

A third question involves the relationship between the region, networks and firms. The positive relationship is clearly demonstrated, but questions persist about the direction of the relationship. Is the positive relationship induced by qualities of the region or regional networks, or is the success of networking due to the presence of particular firms or sectors?

Insight into these aspects will serve the region, by enhancing regional economic performance, and the firm, by helping it define its networking strategy.

\section{References}

Amara, N., R. Landry and M. Ouimet, 2003. Milieux innovateurs: determinants and policy implications. Paper presented at the DRUID Summer conference, Copenhagen, June 12-14 2003. $33 \mathrm{pp}$.

Avermaete, T., J. Viaene, E.J. Morgan and N. Crawford, 2003. Determinants of innovation in small food firms. European Journal of Innovation Management. 6 (1), 8-17.

Avermaete, T., J. Viaene, E.J. Morgan, E. Pitts, N. Crawford and D. Mahon, 2004a. Determinants of product and process innovation in small food manufacturing firms. Trends in Food Science \& Technology 15, 474-486.

Avermaete, T., 2004b. Dynamics of innovation in Small Food Firms. PhD-thesis. Ghent: Ghent University. 170 pp.

Blankenburg Holm, D., K. Eriksson and J. Johanson, 1996. Business networks and cooperation in international business relationships. Journal of international business studies, Special issue 1996, 1033-1053.

Bunnell, T. and N. McCoe, 2001. Spaces and scales of innovation. Progress in Human Geography 25, 4, 569-589.

Bijman, J., R. Tulder and M. Van Vliet, 1998. Internationalisation strategies of agribusiness companies and changing $R \& D$ orientations. In: Ziggers, G., Trienekens, J. and P. Zuurbier (editors). Proceedings of the third international conference on chain management in agribusiness and the food industry. Wageningen, Management studies group, 103-113.

Camps, T., 2004. Chains and networks: theory and practice. In: Camps, T., Diederen, P., Hofstede, G.J. and B. Vos (editors.). The emerging world of chains \& networks. Bridging theory and practice. 's Gravenhage: Reed Business Information, 13-33.

Cassiman, B. and R. Veugelers, 2002. Complementarity in the innovation strategy: internal $R \& D$, external technology acquisition, and cooperation in R\&D. CEPR Discussion Paper 3284, London. 21 pp.

Clarysse, B., R. Van Dierdonck, W. Gabriëls, J. Lambrechts and M. Uytterhaegen, 1998. Strategische verschillen tussen innovatieve KMO's: een kijkje in de zwarte doos. Publication 5, IWT, Brussels.

Daskalakis, M. and M. Kauffeld-Monz, 2005. Trust and knowledge in the behavioural dynamics of innovation networks. Paper presented on the 4th European Meeting on Applied Evolutionary Economics, Utrecht. 26 pp. 
Davenport, M., 2005. Exploring the role of proximity in SME knowledge-acquisition. Research Policy 34, 683-701.

De Noronha Vaz, T. 2004. Strategies for regional development: The effect of policy makers and historical institutional change. In: De Noronha Vaz, T.; Viaene, J. and M. Wigier (editors). Innovation in small firms and dynamics of local development. Warsaw: Scholar Publishing House, 208-224.

Diederen, P., H. Van Meijl and A. Wolters, 2000. Eureka! Innovatieprocessen en innovatiebeleid in de land- en tuinbouw. Den Haag: LEI, Rapport 1.00.04. 89 pp.

De Pelsmacker, P. and P. Van Kenhove, 1994. Marktonderzoek. Methoden en toepassingen. Leuven: Garant. 737 pp.

Earle, M.D., 1997. 'Innovation in the Food industry'. Trends in Food Science and Technology, 8 (5)., 166-175.

Etzkowitz, H. and M. Klofsten, 2005. The innovating region: toward a theory of knowledge-based regional development. R\&D Management 35 (3), 243-255.

Fey, C. and J. Birkinshaw, 2005. External resources of knowledge, governance mode and R\&D performance. Journal of Management, August 2005, 597-621.

Fletcher, R. and N. Barett, 2001. Embeddedness and the evolution of global networks: an Australian case study. Industrial Marketing Management 30 (7), 562-573.

Gellynck, X., P. Verhelst and J. Viaene, 2004. Toekomstige ontwikkeling en potentieel van de land- en tuinbouwsector in het Meetjesland. Report Leader+. Gent: UGent, Vakgroep Landbouweconomie. 205 pp.

Grünert, K., H. Harmsen, M. Meulenberg, E. Kuiper, T. Ottowitz, F. Declerck, B. Traill and G. Göransson, 1997. A framework for analysing innovation in the food sector. In: Traill, B., Grunert, K. (editors), Product and process innovation in the food sector. Suffolk: Chapman \& Hall, 1-33.

Gulati, R., 1999. Network location and learning: the influence of network resources and firm capabilities on alliance formation. Strategic Management Journal 21, 397-420.

Harmesen, H., K. Grunert and F. Declerck., 2000. Why did we make that cheese? An empirically based framework for understanding what drives innovation activity. R\&D Management 30 (2), 151166.

Iammarino, S., 2005. An evolutionary integrated view of Regional Systems of Innovation: concepts, measures and historical perspectives. European Planning Studies 13 (4), 497-519.

Janszen, F. 2002. Systeemdynamische analyse van innovatie in ketens en netwerken. Rotterdam: ISIS Consortium, 35 pp.

Kaufman, A. and P. Wagner, 2005. EU regional policy and the stimulation of innovation: the role of the European Regional Development Fund in the objective 1 region Burgenland. European Planning Studies 13 (4), 582-599.

Lu, J. and P. Beamish, 2001. The internationalization and performance of SMEs. Strategic Management Journal 22, 565586.
Lundvall, B., 1995. National systems of innovation: towards a theory of innovation and interactive learning. London: Biddles Ltd.

Malhotra, N., 1999. Marketing research. An applied orientation. New Jersey: Prentice Hall. 763 pp.

McCoe, N., M. Hess, H. Wai-chung Yeung, P. Dicken and J. Henderson, 2004. 'Globalizing' regional development: a global production networks perspective. Transactions of the Institute of British Geographers, 29 (4), 468-484.

Morrison, P., J. Roberts and D. Midgley, 2003. The nature of lead users and measurement of leading edge status. Research policy 33, 351-362.

Myers, H., 1995. The changing process of internationalisation in the European Union. Service Industries Journal 15 (4), 42-56.

Oerlemans, L., M. Meeus and F. Boekema, 2001. On the spatial embeddedness of innovation networks: an exploration of the proximity effect. Tijdschrift voor Economische en Sociale Geografie 92(1), 60-75.

Omta, O., F. Janszen and M. Batterink, 2004a. Samenwerken aan innovaties. In: Batterink, M., Hoyer, P., Omta, O. and L. Spaans-Dijkstra (editors). Tools voor samenwerking in ketens en netwerken. 's Gravenhage: Reed Business Information, 164 pp.

Omta, O., 2004b. Increasing the innovative potential in chains and networks. Journal on Chain and Network Science 4(2), 75-83.

Pittaway, L., M. Robertson, K. Munir and D. Denyer, 2004. Networking and innovation: a systematic review of the evidence. Lancaster University Management School, working paper 2004/016. 53 pp.

Porter, M., 1998. The competitive advantage of nations. Basingstoke: Macmillan. 855 pp.

Romijn, H. and M. Albaladejo, 2002. Determinants of innovation capability in small electronics and software firms in southeast England. Research Policy 31 (7), 1053-1067.

Streekplatform Meetjesland. 2005. Http://www.meetjesland.be.

Soh, P. and E. Roberts, 2005. Technology alliances and networks: an external link to research capability, IEEE Transactions on engineering management 52 (4), pp. 419-428.

Vermeire, B., J. Viaene, X. Gellynck and B. Van Herck, 2005. Het versterken van de innovatiecapaciteit van de Meetjeslandse agribusiness op basis van locale factorvoordelen. Eindrapport Leader+ Meetjesland. Gent: UGent, vakgroep Landbouweconomie, 140 pp.

Viaene, J. and T. Avermaete, 2004. General discussion and conclusion. In: de Noronha Vaz, T., Viaene, J. and M. Wigier (editors) Innovation in small firms and dynamics of local development. Warsaw: Scholar Publishing House, 227-238. 